\title{
Upaya Pencegahan Stunting dengan Optimalisasi Peran Posyandu Melalui Program Kemitraan Masyarakat
}

\author{
Ika Norcahyanti ${ }^{1)}$ \\ Antonius N. W. Pratama ${ }^{1)}$ \\ Dwi Koko Pratoko ${ }^{1)}$ \\ 1) Universitas Jember \\ norcahyanti.farmasi@unej.ac.id
}

\begin{abstract}
ABSTRAK: Permasalahan gizi yang penting dan perlu mendapat perhatian khusus di Indonesia adalah stunting. Kasus stunting juga ditemukan di Kabupaten Jember, Jawa Timur. Meskipun penanganan stunting membutuhkan waktu yang panjang, intervensi gizi-sensitif dan gizi-spesifik perlu untuk diperkenalkan kepada masyarakat. Kegiatan pengabdian masyarakat ini bertujuan untuk memfasilitasi warga di Posyandu Aster 138A Jember berkaitan dengan upaya pencegahan stunting melalui kegiatan penyuluhan dan budidaya tanaman hidroponik, penyediaan sarana bermain ramah anak serta pelatihan pembuatan makanan tambahan. Kegiatan yang dilakukan selama kurun waktu Juli-September 2019 telah memberikan dampak dan hasil positif berupa peningkatan pengetahuan dan pengalaman dari para kader dan juga anggota Posyandu Aster 138A tentang urban farming melalui budidaya tanaman hidroponik serta pembuatan makanan tambahan dalam bentuk kukis dan nugget yang kaya akan zat besi. Selain itu, pada kegiatan pendirian sarana bermain anak yang dapat merangsang aktivitas motorik juga disambut baik oleh anak-anak yang berada di lingkungan Posyandu Aster 138A. Sebagai kesimpulan, program-program yang mendukung intervensi gizi-sensitif dan gizi spesifik dapat diterima dengan baik oleh masyarakat sasaran. Program seperti ini diharapkan dapat dilakukan berkelanjutan untuk membantu mencegah stunting di Indonesia.
\end{abstract}

Kata kunci : stunting, makanan tambahan kaya zat besi, urban farming, kotak panjat

ABSTRACT: Stunting has currently become an important nutrition problem that needs special attention in Indonesia. Some stunting cases were found in Jember Regency, East Java. Even though stunting could only be treated in a long term, nutrition-sensitive and nutrition-specific interventions are necessary to be introduced to the community. This community service project aimed at facilitating the members of Posyandu Aster 138A Jember to prevent stunting through education and cultivation of hydroponic vegetables, construction of climbing cube, and workshop on cooking supplementary feeding. This activity, which was done between July and September 2019, resulted in positive output and outcome in term of increased knowledge and experience among cadres and members of Posyandu Aster $138 \mathrm{~A}$ in terms of hydroponic urban farming and cooking supplementary feeding in the form of iron-rich cookies and nuggets. The climbing cube that may stimulate the motoric functions was used with pleasure by the children in the area of Posyandu Aster 138A. In conclusion, programs supporting nutrition-sensitive and nutritionspecific intervention can be well accepted by the target community. It is expected that a project like this can be done continuously to help prevent stunting in Indonesia.

Keywords: stunting, iron-rich supplementary feeding, urban farming, climbing cube

\section{PENDAHULUAN}

Saat ini, salah satu permasalahan gizi yang penting dan perlu mendapat perhatian khusus adalah stunting. Stunting merupakan gangguan pertumbuhan fisik berupa 
penurunan kecepatan pertumbuhan secara linear, sehingga anak gagal dalam mencapai potensi tinggi badan yang optimal. Stunting juga dapat dimaknai sebagai kondisi yang terjadi karena dampak kekurangan gizi kronis selama 1.000 hari pertama kehidupan (HPK) anak (Trihono et al., 2015). Dampak yang dapat ditimbulkan akibat kondisi stunting ini dapat bersifat jangka pendek maupun jangka panjang. Dampak jangka pendek mengakibatkan terganggunya perkembangan otak, kecerdasan, gangguan pertumbuhan fisik, dan gangguan metabolisme dalam tubuh. Sementara untuk jangka panjang, stunting dapat mengakibatkan menurunnya kemampuan kognitif dan prestasi belajar serta menurunnya kekebalan tubuh, sehingga anak mudah sakit. Tidak hanya itu, kondisi stunting yang terjadi di Indonesia turut memengaruhi bidang ekonomi. Tercatat dengan nilai PDB tahun 2015 sebesar Rp11.000 triliun, kerugian ekonomi akibat stunting di Indonesia diperkirakan mencapai Rp300 triliun-Rp1.210 triliun per tahun. Prevalensi kejadian stunting di Indonesia sendiri cukup tinggi mencapai 30\%-39\% dan menempatkan Indonesia sebagai negara kelima di dunia dengan jumlah kasus stunting terbanyak (Trihono et al., 2015). Secara umum di Indonesia, kejadian stunting terjadi hampir di seluruh daerah mulai dari Sabang sampai Merauke. Di Provinsi Jawa Timur, berdasarkan hasil Riset Kementerian Kesehatan Tahun 2013, rata-rata prevalensi stunting yang terjadi mencapai 46,6\%, sementara di Kabupaten Jember sendiri mencapai 44,1\% (Kementerian Kesehatan RI, 2013).

Beberapa faktor yang diketahui memengaruhi kejadian stunting di Indonesia antara lain adalah faktor gizi buruk yang dialami oleh ibu hamil dan juga balita, kurangnya pengetahuan ibu mengenai kesehatan dan gizi sebelum dan pada masa kehamilan serta setelah ibu melahirkan, masih terbatasnya layanan kesehatan termasuk layanan antenatal care, postnatal care serta pembelajaran dini yang berkualitas, masih kurangnya akses kepada makanan bergizi, dan kurangnya akses ke air bersih dan sanitasi (Kementerian Desa, Pembangunan Daerah Tertinggal dan Transmigrasi RI, 2017).

Berdasarkan studi pendahuluan yang telah dilakukan di Posyandu Aster 138A Kecamatan Kaliwates, Kabupaten Jember diperoleh informasi bahwa selama ini juga terdapat kasus stunting di wilayah Kecamatan Kaliwates. Para kader posyandu yang telah dibentuk selama ini sudah aktif dalam memberikan pendampingan terutama kepada para ibu hamil dan menyusui terkait upaya-upaya yang dapat dilakukan dalam pencegahan stunting termasuk secara rutin memberikan edukasi tentang ASI eksklusif dan pemberian makanan tambahan seperti biskuit bergizi. Tetapi masih terdapat permasalahan, yaitu meski para kader memiliki semangat yang tinggi, namun belum terdapat legalitas pendirian posyandu bahkan sejak posyandu berdiri di tahun 2012, padahal jumlah sasaran balita yang selama ini ditangani mencapai 150 balita. Selain itu, letak posyandu Aster 138A yang berada di kawasan perumahan juga belum diimbangi dengan pemanfaatan fasilitas umum (fasum) berupa lahan kosong yang dapat mendukung pemberdayaan masyarakat terutama di kalangan ibu-ibu sekaligus yang juga dapat mendukung upaya peningkatan gizi masyarakat. 
Berbagai permasalahan yang dihadapi oleh mitra terkait stunting yang telah dipaparkan pada bagian pendahuluan dapat diatasi masing-masing dengan kombinasi solusi intervensional yang terbagi ke dalam dua kelompok besar, yaitu pemberian program gizi-spesifik dan gizi-sensitif. Selain itu, edukasi dan pelatihan secara bertahap juga akan diberikan kepada mitra Posyandu. Sesuai dengan laporan sebuah systematic review, kombinasi kedua hal tersebut diketahui lebih mampu memberikan dampak yang signifikan dibandingkan jika dilaksanakan secara terpisah (Hossain et al., 2017).

Program gizi-spesifik adalah program yang berkaitan dengan perbaikan status gizi secara langsung (Hossain et al., 2017; Putri, Arimbi, \& Fauzi, 2016). Sasaran program ini terutama adalah anak yang masih berada pada masa 1000 HPK dan atau ibu hamil dan menyusui. Program ini bersifat jangka pendek. Pada usulan ini, program gizi-spesifik diwujudkan melalui pelatihan fortifikasi zat besi pada makanan tambahan berupa nugget dan kukis. Sementara, program gizi-sensitif adalah program yang tidak secara langsung berkaitan dengan kesehatan, tetapi berdampak pada gizi masyarakat (Putri et al., 2016). Berbeda dari gizi-spesifik, dampak program gizi-sensitif ini untuk jangka panjang dan berkesinambungan. Program gizi-sensitif yang diusulkan dalam program kemitraan masyarakat ini adalah urban farming menggunakan cara hidroponik dan pembuatan sarana bermain ramah anak. Asupan sayuran segar dari budidaya hidroponik dapat menjadi sumber gizi tambahan untuk anggota keluarga terutama bagi ibu hamil dan menyusui serta balita dan anak-anak. Di sisi lain, sarana bermain yang aman dan ramah untuk anak dapat menstimulasi pertumbuhan tulang anak (Specker \& Binkley, 2003).

\section{METODE PELAKSANAAN}

\section{Urban farming melalui budidaya tanaman hidroponik}

Metode yang dilakukan pada kegiatan urban farming melalui budidaya tanaman hidroponik ini diawali dengan observasi lanjutan di lingkungan posyandu Aster 138A sekaligus melakukan koordinasi dengan ketua RT dan para kader posyandu setempat terkait jumlah warga yang akan dilibatkan dalam pelatihan beserta penetapan waktu dan lokasi penyelenggaraan termasuk menyelesaikan pengurusan administrasi kegiatan. Langkah selanjutnya adalah melakukan sosialisasi mengenai kegiatan yang akan dilaksanakan dan disusul dengan penyebaran undangan kepada para peserta pelatihan. Setelah waktu penyelenggaraan tiba, maka kegiatan akan diawali oleh pemberian penyuluhan tentang pemanfaatan lahan kosong dalam upaya peningkatan gizi masyarakat dan mengenalkan teknik hidroponik. Setelah penyuluhan dilaksanakan, dilanjutkan dengan pelatihan pembuatan bibit semai tanaman hidroponik menggunakan alat dan bahan yang telah disediakan serta pembuatan nutrisi sembari dibuka diskusi terkait pengelolaan tanaman hidroponik.

Kegiatan penyuluhan dan pelatihan budidaya hidroponik dilaksanakan pada bulan Agustus dan September 2019 dimana mitra Kader Posyandu Aster 138A diperkenalkan oleh Tim PKM kepada kelompok pegiat hidroponik Jember dan kelompok ini pula yang memberikan kegiatan penyuluhan dan pelatihan.

Dua instalasi hidroponik disumbangkan kepada mitra. Ukuran masing-masing instalasi menyesuaikan luas lahan yang sebelumnya telah disepakati bersama oleh warga. 
Perawatan instalasi hidroponik dan hasil panen disepakati bersama oleh para kader posyandu.

\section{Fortifikasi zat besi pada makanan tambahan}

Metode yang dilakukan pada kegiatan fortifikasi zat besi ini diawali dengan observasi lanjutan di lingkungan posyandu Aster 138A sekaligus melakukan koordinasi dengan ketua RT dan para kader posyandu setempat terkait jumlah warga yang akan dilibatkan dalam pelatihan beserta penetapan waktu dan lokasi penyelenggaraan termasuk menyelesaikan pengurusan administrasi kegiatan. Langkah selanjutnya adalah melakukan sosialisasi mengenai kegiatan yang akan dilaksanakan dan disusul dengan penyebaran undangan kepada para kader posyandu dan peserta pelatihan. Setelah waktu penyelenggaraan tiba, maka kegiatan akan diawali oleh pemberian penyuluhan tentang pemanfaatan kacang hijau, bayam, wortel, dan daging ayam dalam pembuatan kukis dan nugget bagi pemenuhan gizi untuk ibu hamil dan menyusui serta balita dan anak-anak. Setelah penyuluhan dilaksanakan, dilanjutkan dengan pelatihan pembuatan kukis dan nugget bergizi menggunakan alat dan bahan yang telah disediakan sembari dibuka diskusi apabila masih terdapat pertanyaan dari para peserta pelatihan. Kegiatan penyuluhan dan pelatihan pembuatan kukis dan nugget bergizi dilaksanakan pada bulan September 2019.

\section{Sarana bermain ramah anak dan aman}

Metode yang dilakukan pada kegiatan pembuatan sarana bermain ramah anak ini diawali dengan observasi lanjutan di lingkungan posyandu Aster 138A sekaligus melakukan koordinasi dengan ketua RT dan ketua kader posyandu setempat. Langkah selanjutnya adalah melakukan diskusi dan sosialisasi mengenai kegiatan yang akan dilaksanakan termasuk diskusi dengan bengkel penyedia dan pihak warga. Dalam sosialisasi dan diskusi akan dibahas terkait pemanfaatan sarana bermain untuk menstimulasi kemampuan motorik anak, dan perlu ditekankan bahwa sarana bermain yang dibuat akan memerhatikan aspek keamanan dan kenyamanan. Kegiatan pembuatan sarana bermain ramah anak ini dilaksanakan pada Juli-Agustus 2019.

\section{HASIL DAN PEMBAHASAN}

\section{Urban farming melalui budidaya tanaman hidroponik}

Sebelum penyuluhan dan pelatihan, mitra bersepakat bahwa instalasi hidroponik akan diletakkan di rumah dua kader posyandu terpilih. Setelah dilakukan survei oleh pihak pembuat instalasi, lahan di rumah salah satu kader posyandu terpilih dinilai kurang cocok dan memadai untuk pertumbuhan optimal tanaman hidroponik karena menghadap ke arah Barat. Berdasarkan hal tersebut, lokasi instalasi dipindahkan ke rumah kader posyandu lainnya.

Kegiatan penyuluhan dan pelatihan budidaya hidroponik dilakukan di rumah ketua kader Posyandu Aster 138A sebanyak dua kali. Pertemuan pertama untuk memberikan pengetahuan dasar tentang teknik hidroponik dan pelatihan penyemaian benih hidroponik. Pertemuan kedua dilakukan setelah benih sayur (pakcoy, kailan, bayam merah) sudah siap dipindahkan ke instalasi hidroponik. Pada pertemuan kedua ini materi pelatihan yang diberikan terkait pemindahan benih, penyiapan dan pengelolaan nutrisi, dan dasar perawatan instalasi. Antusiasme peserta nampak melalui banyaknya pertanyaan 
yang diajukan. Para fasilitator pun antusias dalam memberikan jawaban-jawaban yang praktis dan mudah dilakukan untuk skala rumah tangga.

Panen pertama tanaman hidroponik telah dilakukan. Hasil panen cukup memuaskan dengan ukuran sayur yang relatif besar. Sayur panenan sebagian dikonsumsi oleh para kader serta anggota posyandu dan sebagian lain terjual cepat di grup-grup aplikasi pesan komunal Dasa Wisma yang terkait dengan Posyandu Aster 138A.

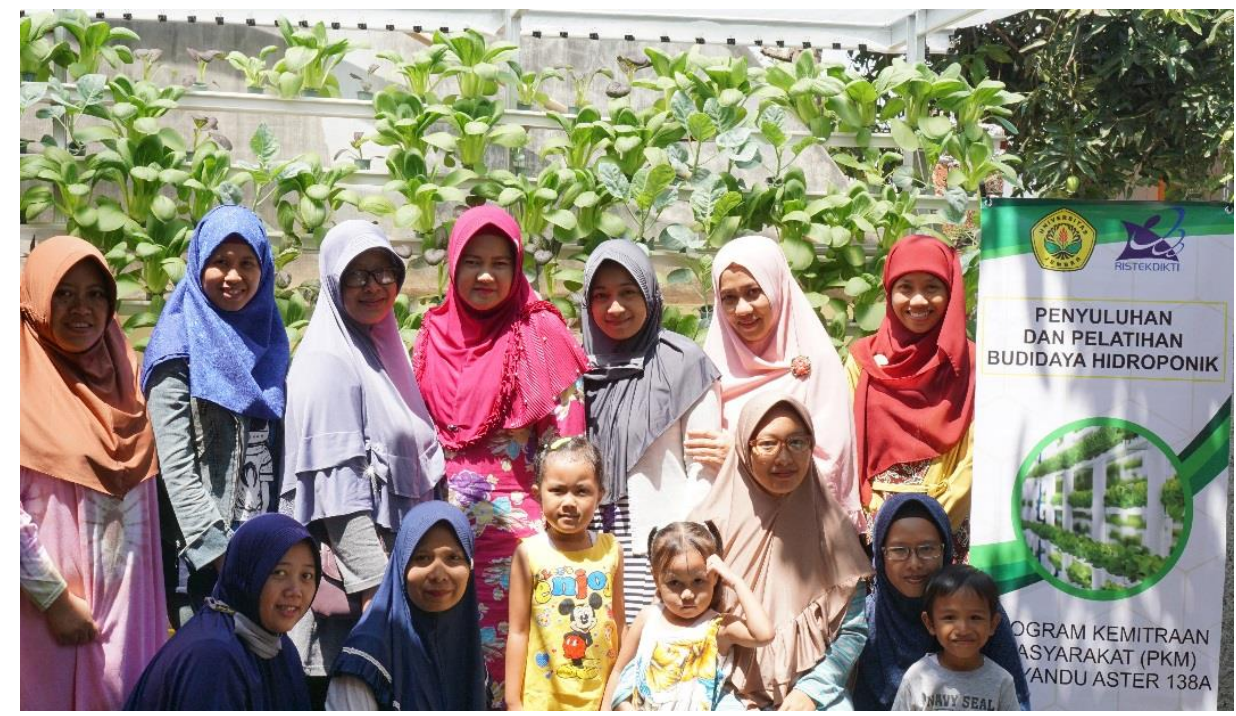

Gambar 1. Penyuluhan dan pelatihan budidaya hidroponik di Posyandu Aster 138A

\section{Sarana bermain ramah anak dan aman}

Instalasi sarana bermain sederhana diputuskan melalui rapat rukun tetangga di salah satu lokasi fasilitas umum perumahan. Lokasi ini sering dipakai untuk latihan voli rutin dan mudah diakses oleh anak-anak. Sarana bermain yang dibuat di lokasi taman bermain ini adalah kotak panjat. Kotak ini terbuat dari besi kokoh dengan jaring-jaring tali pada sisi kanan, kiri, dan atas. Anak-anak dapat memanjat hingga atas kotak. Bagian dasar kotak tidak diberi bak pasir, tetapi direncanakan akan ditanami rumput. Tinggi kotak di atas permukaan tanah sekitar $170 \mathrm{~cm}$, sehingga tidak terlalu tinggi. 


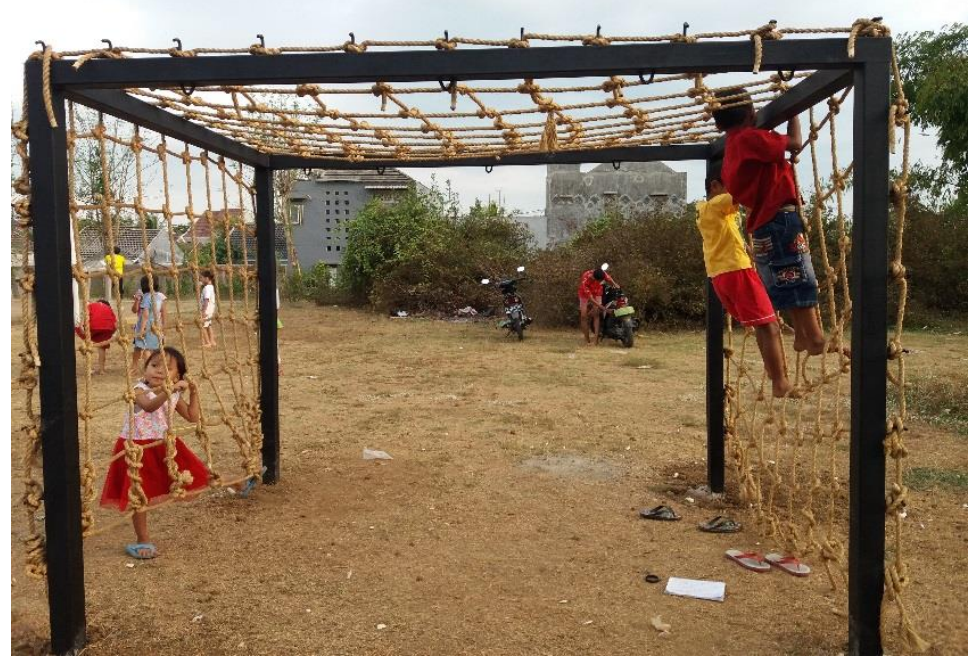

Gambar 2. Instalasi kotak panjat di fasilitas umum

\section{Fortifikasi zat besi pada makanan tambahan}

Penyuluhan dan pelatihan pembuatan makanan tambahan dilaksanakan di salah satu kader posyandu pada bulan September 2019. Pada pelatihan pembuatan makanan tambahan ini disepakati bahwa produk yang dibuat adalah berupa kukis kacang hijau dan nugget kombinasi bayam, wortel, dan daging ayam. Bahan-bahan utama tersebut dipilih dengan pertimbangan bahwa di dalam bahan-bahan tersebut terdapat kandungan zat besi yang sangat dibutuhkan baik oleh ibu hamil dan menyusui maupun balita dan anak-anak dalam rangka mencegah terjadinya stunting. Pelatihan berjalan dengan lancar diikuti dengan antusiasme para peserta yang bertanya saat jalannya pelatihan. Setelah dua produk selesai dibuat, terlihat ketertarikan dari beberapa anak yang juga hadir untuk mencicipi dua produk tersebut.

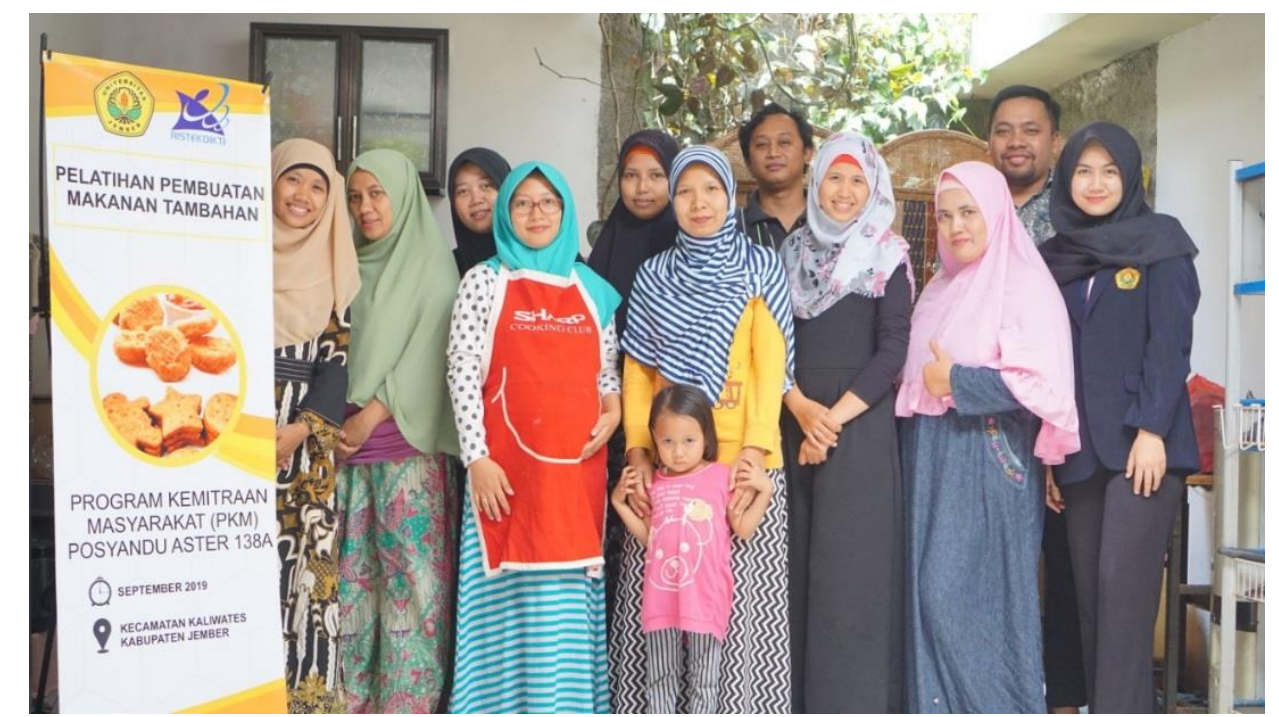

Gambar 3. Pelatihan pembuatan kukis kacang hijau dan nugget bayam wortel 


\section{UCAPAN TERIMA KASIH}

Penulis menyampaikan ucapan terima kasih kepada DRPM Kemenristekdikti dan kepada kedua orang mahasiswa yang telah membantu dalam pelaksanaan kegiatan yakni Zion Mahardikara dan Ghea Ananda.

\section{KESIMPULAN DAN SARAN}

\section{Kesimpulan}

Program-program yang mendukung intervensi gizi-sensitif dan gizi spesifik dapat diterima dengan baik oleh masyarakat sasaran, Posyandu Aster 138A. Hal ini dibuktikan dengan adanya peningkatan pengetahuan dan pengalaman dari para kader dan juga anggota Posyandu Aster 138A tentang urban farming melalui budidaya tanaman hidroponik serta pembuatan makanan tambahan dalam bentuk kukis dan nugget yang kaya zat besi. Selain itu, pada kegiatan pendirian sarana bermain anak yang dapat merangsang aktivitas motorik juga disambut baik oleh anak-anak yang berada di lingkungan Posyandu Aster 138A.

\section{Saran}

Diperlukan kegiatan serupa yang dapat dilakukan pada kader maupun anggota posyandu lainnya di wilayah Kabupaten Jember, sehingga mereka dapat memiliki pengetahuan dan pengalaman dalam melakukan contoh-contoh upaya intervensi gizispesifik dan gizi sensitif dalam rangka mencegah terjadinya stunting di Indonesia.

\section{DAFTAR PUSTAKA}

Allen, L., De Benoist, B., Dary, O., \& Hurrell, R. 2006. Guidelines on food fortification with micronutrients. Geneva: World Health Organization. Retrieved from http://www.who.int/nutrition/publications/guidefoodfortification_micronutrients.p df

Hossain, M., Choudhury, N., Adib Binte Abdullah, K., Mondal, P., Jackson, A. A., Walson, J., \& Ahmed, T. 2017. Evidence-based approaches to childhood stunting in low and middle income countries: a systematic review. Archives of Disease in Childhood, 102(10), 903-909. https://doi.org/10.1136/archdischild-2016-311050

Kementerian Desa, Pembangunan Daerah Tertinggal, dan Transmigrasi RI. 2017. Buku Saku Desa dalam Penanganan Stunting. Jakarta: Kementerian Desa, Pembangunan Daerah Tertinggal, dan Transmigrasi RI.

Kementerian Kesehatan RI. Riset Kesehatan Dasar Tahun 2013. Jakarta: Kementerian Kesehatan RI.

Putri, O. Q., Arimbi, D. Q., \& Fauzi, H. D. 2016. Study on Stunting Prevention Program in Indonesia: A Literature Review. ASEAN/Asian Academic Society International Conference Proceeding Series, 0(0). Retrieved from http://aasic.org/proc/aasic/article/view/140 
Specker, B., \& Binkley, T. 2003. Randomized trial of physical activity and calcium supplementation on bone mineral content in 3 to 5 year old children. Journal of Bone and Mineral Research, 18(5), 885-892. https://doi.org/10.1359/jbmr.2003.18.5.885

Trihono, Atmarita, Tjandrarini, D.H., Irawati, A., Utami, N.H., Tejayanti, T., Nurlinawati, I. 2015. Pendek (Stunting) di Indonesia, Masalah, dan Solusinya. Jakarta: Lembaga Penerbit Badan Penelitian dan Pengembangan Kesehatan Kementerian Kesehatan RI.

World Health Assembly. 2012. WHA Global Nutrition Target 2025: Stunting Policy Brief. 